\title{
Digestion of complex carbohydrates and large bowel fermentation in rats fed on raw and cooked peas (Pisum sativum)
}

\author{
BY J.S. GOODLAD*AND J. C. MATHERS† \\ Department of Agricultural Biochemistry and Nutrition, University of Newcastle upon Tyne, \\ Newcastle upon Tyne NEI $7 R U$
}

(Received 1 February 1991-Accepted 5 July 1991)

\begin{abstract}
Rats were fed on four semi-purified diets in which raw or cooked peas (Pisum sativum var. Sentinel) provided 250 or $500 \mathrm{~g} / \mathrm{kg}$ diet. Pressure-cooking of peas followed by rapid freezing and freeze-drying increased the proportion of starch resistant to $\alpha$-amylase $(E C 3.2 .1$.1) without previous treatment with dimethyl sulphoxide. There were only minor effects of cooking on the digestibilities of non-starch polysaccharides and their constituent sugars. With the higher dietary pea concentration there were marked increases in the flow of organic matter to, and fermentation in, the large bowel. These increases were associated with significant increases in colonic tissue and contents weights, and in colonic transit time. Both cooking and dietary pea inclusion rate altered the pattern of volatile fatty acids in caecal contents and in portal blood.
\end{abstract}

Complex carbohydrates: Large bowel fermentation: Cooking: Peas

Leguminous seeds are normally cooked before being eaten. With beans, cooking improves nutritional value by destroying heat-labile anti-nutritional factors such as lectins (Liener \& Kakade, 1980; Huisman et al. 1990). Peas (Pisum sativum) also contain lectins (Sharon \& Halina, 1972), but these are present in very low concentrations (Grant et al. 1983; Goodlad, 1989) so that raw peas can be included in the diets of rats and pigs at up to $500 \mathrm{~g} / \mathrm{kg}$ diet without adverse effects (Goodlad \& Mathers, 1990, 1991). Although cooking is not essential for safe consumption of peas, thermal processing affects the carbohydrate fraction of the seed, in particular the starch. Mature peas contain approximately $470 \mathrm{~g}$ starch $/ \mathrm{kg}$ dry matter (DM) (Paul \& Southgate, 1978; Goodlad, 1989) of which almost one-third is as amylose (Orford et al. 1987; S. Cooper, R. M. Weightman \& J. C. Mathers, unpublished results). Heating starch or starch-rich food in the presence of water results in gelatinization of the starch with preferential solubilization of amylose (Orford et al. 1987). This gelatinization increases the rate at which starch is hydrolysed by pancreatic $\alpha$-amylase $(E C$ 3.2.1.1) in vitro (Holm et al. 1988) and results in larger post-prandial concentrations of glucose and insulin in peripheral blood (Collings et al. 1981; O'Dea et al. 1981). On cooling to below $60^{\circ}$, starch undergoes retrogradation (a crystallization process; Collinson, 1968) leading to the formation of robust gels (Orford et al. 1987) in which some of the starch is resistant to $\alpha$-amylase (RS; Englyst \& Cummings, 1987). This appears to be mainly retrograded amylose and has been classified as $\mathrm{RS}_{3}$ by Englyst \& Kingman (1990). The extent of retrogradation depends on the starch source, with cereal starches retrograding more quickly than tuber starches because of their higher amylose content (Collinson, 1968; Orford et al. 1987). The conditions used for cooking and drying also affect the extent of RS

* Present address: Pedigree Petfoods, Mill Street, Melton Mowbray, Leics. LE13 IBB.

$\dagger$ For reprints. 
formation (Englyst \& Cummings, 1987). Effects of cooking on the non-starch polysaccharides (NSP) fraction in foods are poorly understood. For wheat flour, apparent increases in total dietary fibre with extrusion cooking seem to be due largely to the formation of RS (Björck et al. 1984). Baking and extrusion cooking of barley-based diets appear to increase the proportion of NSP which is soluble (Fadel et al. 1988, 1989), possibly as a result of depolymerization (Waldron \& Selvendran, 1990).

Tissue softening and depolymerization of NSP following cooking (Waldron \& Selvendran, 1990) may influence bacterial colonization and rate of fermentation within the large bowel (LB). In addition, alteration in the rate of starch digestion in the small bowel is likely to influence the nature and quantity of organic matter (OM) flowing into the LB with consequences for the amount of carbohydrate fermented in that organ. Changes in substrate supply probably alter the pattern of volatile fatty acids (VFA) produced (Macfarlane \& Englyst, 1986; Cheng et al. 1987; Key \& Mathers, 1987), and the amount of energy salvaged by the LB (Mathers, 1991), and may have other physiological effects (Cummings \& Englyst, 1987; Wyatt et al. 1988). The present study was designed to compare the digestion of complex carbohydrates and large bowel fermentation in rats fed on raw and cooked peas, each provided at two dietary concentrations.

\section{MATERIALS AND METHODS}

\section{Animals and housing}

Thirty-two male Wistar rats (A. Tuck \& Sons, Essex) with initial weight 134 (SE 2.2) g were randomly allocated in pairs to stock cages and each fed $20 \mathrm{~g}$ of the appropriate experimental diet (see Table 1) daily. After $10 \mathrm{~d}$, four groups of seven rats were randomly allocated to individual Perspex and stainless-steel metabolism cages (Thompson, 1970) which permitted complete separation and collection of urine and faeces.

\section{Diets and feeding}

Four semi-purified diets were formulated (Table 1) to contain two concentrations ( 250 or $500 \mathrm{~g} / \mathrm{kg}$ ) of either milled cooked or raw peas (var. Sentinel), with balancing alterations in sucrose and casein to maintain similar crude protein (nitrogen $\times 6.25$ ) and calculated metabolizable energy (ME) contents. Autoclaved maize starch (the only source of complex carbohydrate in addition to peas) was present in equal concentrations in all diets, as was the non-absorbed marker chromic oxide.

Whole dried peas were pressure-cooked in an equal volume of distilled water for $25 \mathrm{~min}$. No water needed to be drained after cooking. Portions of the hot peas were immediately immersed in liquid $\mathrm{N}_{2}$ for rapid freezing, followed by freeze-drying. Freeze-dried cooked peas and raw peas were hammer-milled to pass a $1 \mathrm{~mm}$ screen before incorporation into the diets. Each animal received $20 \mathrm{~g}$ air-dry ration at 10.00 hours daily. The ration was usually consumed by 13.00 hours. Any food residues were removed daily, dried and weighed. Water was available ad lib.

\section{Experimental protocol}

After $10 \mathrm{~d}$ in stock cages and $7 \mathrm{~d}$ in metabolism cages there followed a $7 \mathrm{~d}$ balance period with total collection of faeces and urine, and measurement of food intake. The appropriate experimental diets were fed throughout the whole of this $24 \mathrm{~d}$ study. Animals were weighed at the beginning and end of the balance period, and on the days of slaughter.

Animals were anaesthetized and blood, digesta and tissue samples were collected as described by Goodlad \& Mathers (1990). In addition, the masses of colon and of colonic tissue were measured. Fourteen animals were sampled on each of two consecutive days. 
Table 1. Formulation $(\mathrm{g} / \mathrm{kg})$ and analysed composition $(\mathrm{g} / \mathrm{kg}$ dry matter $(D M))$ of diets

\begin{tabular}{|c|c|c|c|c|}
\hline Diet ... & $\mathrm{LC}$ & $\mathrm{HC}$ & LR & HR \\
\hline Raw peas (Pisum sativum $)^{*}$ & 0 & 0 & 250 & 500 \\
\hline Cooked peas $\dagger$ & 250 & 500 & 0 & 0 \\
\hline Maize starch $\ddagger$ & 398 & 398 & 398 & 398 \\
\hline Sucrose & 190 & 0.6 & 190 & 0.6 \\
\hline Casein & 95 & 33 & 95 & 33 \\
\hline Maize oil & 33 & 33 & 33 & 33 \\
\hline Vitamin and mineral mix $\S$ & $31 \cdot 7$ & $31 \cdot 7$ & $31 \cdot 7$ & $31 \cdot 7$ \\
\hline L-methionine & $2 \cdot 3$ & $3 \cdot 9$ & $2 \cdot 3$ & 3.9 \\
\hline \multicolumn{5}{|l|}{$\begin{array}{l}\text { Analysed composition } \\
\text { (g/kg DM) }\end{array}$} \\
\hline Organic matter & 967 & 959 & 958 & 947 \\
\hline $\begin{array}{l}\text { Crude protein } \\
\text { (nitrogen } \times 6.25 \text { ) }\end{array}$ & 144 & 150 & 149 & 149 \\
\hline Total NSP & $25 \cdot 9$ & $63 \cdot 3$ & $29 \cdot 3$ & $64 \cdot 7$ \\
\hline Cellulose & $9 \cdot 8$ & $25 \cdot 0$ & $12 \cdot 6$ & $28 \cdot 7$ \\
\hline NCP & $16 \cdot 7$ & $38 \cdot 3$ & $16 \cdot 7$ & $36 \cdot 0$ \\
\hline Arabinose & $6 \cdot 3$ & $15 \cdot 1$ & $7 \cdot 5$ & $16 \cdot 2$ \\
\hline Xylose & $1 \cdot 5$ & $4 \cdot 6$ & $2 \cdot 0$ & $6 \cdot 1$ \\
\hline Galactose & $1 \cdot 1$ & $3 \cdot 3$ & $1 \cdot 4$ & $3 \cdot 2$ \\
\hline Glucose & 16.9 & $38 \cdot 7$ & $18 \cdot 5$ & 35.8 \\
\hline Uronic acids & $0 \cdot 03$ & 0.07 & $0 \cdot 04$ & 0.08 \\
\hline Resistant starch & $7 \cdot 6$ & $14 \cdot 5$ & $3 \cdot 9$ & 3.6 \\
\hline $\begin{array}{l}\text { Calculated energy content } \\
\text { (MJ ME/kg) }\end{array}$ & $14 \cdot 4$ & $14 \cdot 0$ & $14 \cdot 4$ & $14 \cdot 0$ \\
\hline
\end{tabular}

LC, HC, LR, HR low (L) and high (H) levels of cooked (C) and raw (R) peas; NSP, non-starch polysaccharide; NCP, non-cellulosic polysaccharide; ME, metabolizable energy.

* var. Sentinel milled to pass a $1 \mathrm{~mm}$ screen.

$\uparrow$ Pressure cooked for 25 min (for details, see p. 476).

\$ Autoclaved at $120^{\circ}$ for $20 \mathrm{~min}$, freeze-dried and milled to pass a $1 \mathrm{~mm}$ screen.

$\S$ For details, see Goodlad \& Mathers (1990).

\section{Analytical methods}

NSP and its constitutents were determined as described by Englyst \& Cummings (1984) and RS by omitting the dimethyl sulphoxide (DMSO) addition step. $\mathrm{N}$ in diets, faeces and urine was measured by a $\mathrm{Kjeldahl}$ procedure, $\mathrm{Cr}_{2} \mathrm{O}_{3}$ and volatile fatty acids (VFA) in caecal digesta as described by Mathers et al. (1990), organic matter (OM) by heating at $500^{\circ}$ for $16 \mathrm{~h}$, and 3-hydroxybutyrate (3OHB) in deproteinized blood enzymically (Lloyd et al. 1978). Concentrations of VFA in portal and heart blood were determined as described by Goodlad \& Mathers (1990).

\section{Statistical methods}

Data were examined by one-way analysis of variance with orthogonal contrasts (Ridgman, 1975) used to test: (1) effects of dietary concentration of peas, i.e. contrast 1 was (low, cooked (LC) + low, raw (LR)) v. (high, cooked (HC) + high, raw (HR)), (2) effects of cooking, i.e. contrast 2 was $(\mathrm{LC}+\mathrm{HC}) v$. $(\mathrm{LR}+\mathrm{HR})$ and $(3)$ interactions between dietary concentration and cooking, i.e. contrast 3 was $(\mathrm{LC}+\mathrm{HR})$ v. $(\mathrm{HC}+\mathrm{LR})$. Results are presented as means for each diet $(n 7)$ with their standard errors based on between-animals within-diets variation. 
Table 2. Dry matter $(D M)$ intake $(g / 7 d)$, growth rate $(g / 7 d)$, liver weight $(g)$ and aspects of nitrogen metabolism $(\mathrm{g} / 7 \mathrm{~d})$ in rats given diets containing raw $(R)$ or cooked $(C)$ peas (Pisum sativum var. Sentinel) at two inclusion rates $(250(L)$ and $500(H) \mathrm{g} / \mathrm{kg})$

(Means for seven rats per diet)

\begin{tabular}{|c|c|c|c|c|c|c|c|c|}
\hline \multirow[b]{2}{*}{ Diet $† \ldots$} & \multirow[b]{2}{*}{$\mathrm{LC}$} & \multirow[b]{2}{*}{$\mathrm{HC}$} & \multirow[b]{2}{*}{ LR } & \multirow[b]{2}{*}{ HR } & \multirow[b]{2}{*}{ SEM } & \multicolumn{3}{|c|}{$\begin{array}{c}\text { Statistical significance of } \\
\text { dietary effects }\end{array}$} \\
\hline & & & & & & $\begin{array}{l}\text { Inclusion } \\
\text { rate }\end{array}$ & Cooking & Interaction \\
\hline DM intake & 127 & 121 & 126 & 123 & 0.9 & $* * *$ & NS & NS \\
\hline Growth rate & $39 \cdot 2$ & $40 \cdot 6$ & $44 \cdot 1$ & $39 \cdot 9$ & $1 \cdot 12$ & NS & NS & $*$ \\
\hline Liver wt & $11 \cdot 0$ & $9 \cdot 2$ & 10.9 & $9 \cdot 9$ & $0 \cdot 26$ & $* * *$ & NS & NS \\
\hline $\mathrm{N}$ metabolism & & & & & & & & \\
\hline $\mathrm{N}$ intake & $2 \cdot 93$ & 2.91 & 3.01 & $2 \cdot 95$ & 0.023 & NS & $*$ & NS \\
\hline Faecal N & $0 \cdot 36$ & 0.52 & 0.39 & 0.51 & 0.016 & $* * *$ & NS & NS \\
\hline Urinary $\mathrm{N}$ & 0.88 & 0.81 & 0.90 & 0.81 & 0.065 & NS & NS & NS \\
\hline N retention & 1.69 & 1.59 & 1.72 & 1.63 & 0.056 & NS & NS & NS \\
\hline
\end{tabular}

RESULTS

The most striking effect of cooking of peas on diet composition was the 2-4-fold increase in the concentration of starch resistant to pancreatic $\alpha$-amylase without previous treatment with DMSO (RS; Table 1). Concentrations of NSP and of its constituent sugars were similar for raw- and cooked-pea diets and increased approximately 2-fold when pea inclusion rate increased from 250 to $500 \mathrm{~g} / \mathrm{kg}$ diet. The lower-than-expected NSP concentration for diet LC was due largely to the apparently lower cellulose content of this diet.

\section{Rat growth and $N$ metabolism}

All diets were well-accepted by the rats; food refusals were negligible and growth rates good (Table 2). The statistically significant $(P<0.05)$ interaction between pea inclusion rate and cooking was due to a $10 \%$ higher growth rate on the LR diet whilst growth rates for the other three diets were very similar. Higher intakes of peas were associated with higher faecal $\mathrm{N}$ outputs $(P<0.01)$, but these were balanced by a tendency (not significant) towards reduced urinary $\mathrm{N}$ outputs so that $\mathrm{N}$ retention was not statistically different between diets.

\section{Sites and extents of $D M$ and $O M$ digestion}

Cooking of peas had no significant effects on the extent of digestion of dietary DM in the upper or the lower intestine. However, increasing the proportion of peas from 250 to 500 $\mathrm{g} / \mathrm{kg}$ diet caused a large fall in DM digestibility anterior to the caecum and, although this was compensated for by increased LB digestion, whole gut digestibility of DM was significantly reduced $(P<0.001)$. Estimates of DM digestibility measured at the colon and in faeces were similar. Mouth-to-anus digestibilities of DM were calculated from total DM intakes and faecal outputs during the $7 \mathrm{~d}$ balance period and by the marker ratio technique, with both methods giving similar results (Table 3 ). Faecal recovery of the indigestible flow marker $\mathrm{Cr}_{2} \mathrm{O}_{3}$ was 1.07 (SE 0.012). 
Table 3. Apparent dry matter (DM) digestibility $\uparrow$ measured at various sampling sites in rats given diets containing raw $(R)$ or cooked $(C)$ peas (Pisum sativum var. Sentinel) at two inclusion rates $(250(\mathrm{~L})$ and $500(\mathrm{H}) \mathrm{g} / \mathrm{kg})$

(Means for seven rats per diet)

\begin{tabular}{|c|c|c|c|c|c|c|c|c|}
\hline \multirow[b]{2}{*}{$\operatorname{Diet}_{+}^{+} \ldots$} & \multirow[b]{2}{*}{ LC } & \multirow[b]{2}{*}{$\mathrm{HC}$} & \multirow[b]{2}{*}{ LR } & \multirow[b]{2}{*}{$\mathrm{HR}$} & \multirow[b]{2}{*}{ SEM } & \multicolumn{3}{|c|}{$\begin{array}{c}\text { Statistical significance of } \\
\text { dietary effects§ }\end{array}$} \\
\hline & & & & & & $\begin{array}{l}\text { Inclusion } \\
\text { rate }\end{array}$ & Cooking & Interaction \\
\hline Terminal ileum & 0.81 & 0.74 & 0.81 & 0.73 & 0.018 & $* * *$ & NS & NS \\
\hline Colon & 0.95 & 0.93 & $0 \cdot 95$ & 0.93 & 0.003 & $* * *$ & NS & NS \\
\hline Faeces & 0.94 & $0 \cdot 91$ & 0.94 & 0.91 & 0.002 & $* * *$ & NS & NS \\
\hline Facees (method 1 ) & 0.94 & 0.91 & 0.94 & 0.91 & 0.002 & $* * *$ & NS & NS \\
\hline
\end{tabular}

NS, not significant.

*** $P<0.001$.

+ Digestibilities were determined by the marker ratio method except for faeces (method 1) calculated on the basis of total faecal collection.

+ For details of composition, see Table 1.

$\$$ For details of orthogonal contrasts, see p. 477.

With the higher dietary concentration of peas, flows of DM and of OM to the LB were significantly increased and were accompanied by mean increased net daily disappearances of $0.68 \mathrm{~g} \mathrm{DM}$ and $0.92 \mathrm{~g} \mathrm{OM}$, so that OM disappearance in the LB with diets HC and HR was almost twice as great as with the LC and LR diets (Table 4).

\section{Mass of LB tissue and digesta}

Weights of whole caecum, caecal tissue and wet caecal contents tended to increase with the higher intakes of peas but the differences were not significant (Table 5). Caecal digesta DM was significantly $(P<0.05)$ increased with diets $\mathrm{HC}$ and $\mathrm{HR}$, when compared with LC and LR, due to the combination of slightly higher wet contents weight and slightly higher proportion of DM in the digesta. Caecal transit time (TT) was about one-third shorter for the HR than for the LR diet with both cooked-pea diets (LC and HC) giving intermediate and more similar TT (Table 5). For the colon, the results were much clearer with the higherpea diets (HC and HR) resulting in significantly greater weights for the whole colon, colonic tissue and colonic wet digesta and DM contents and significantly $(P<0 \cdot 05)$ longer TT. Cooking peas had no significant effect on any of these variables.

\section{Caecal $\mathrm{pH}$ and fermentation pattern}

Caecal pH was significantly reduced by consumption of the higher-pea diets whilst total VFA concentration increased (Table 6). The latter was also markedly higher for the cookedpea-containing diets than for the raw-pea-containing diets. The proportion of peas in the diet had no significant effects on the molar proportions of the three major VFA (acetate, propionate and butyrate), but cooking was associated with significantly higher molar proportions of acetate and lower proportions of propionate. Molar proportions of isobutyrate, isovalerate and valerate were lower for the cooked-pea diets than for the rawpea diets and were reduced with the higher dietary pea inclusion rate. Hexanoate was detected in caecal contents of rats on all diets with no significant between-diets effects. 
Table 4. Flows $(\mathrm{g} / \mathrm{d})$ of dry matter and organic matter to, and disappearance in, the large bowel $(L B)$ of rats given diets containing raw $(R)$ or cooked $(C)$ peas (Pisum sativum var. Sentinel) at two inclusion rates $(250(\mathrm{~L})$ and $500(\mathrm{H}) \mathrm{g} / \mathrm{kg})$

(Means for seven rats per diet)

\begin{tabular}{|c|c|c|c|c|c|c|c|c|}
\hline \multirow[b]{2}{*}{$\operatorname{Diet}^{\dagger} \ldots$} & \multirow[b]{2}{*}{$\mathrm{LC}$} & \multirow[b]{2}{*}{$\mathrm{HC}$} & \multirow[b]{2}{*}{ LR } & \multirow[b]{2}{*}{ HR } & \multirow[b]{2}{*}{ SEM } & \multicolumn{3}{|c|}{$\begin{array}{c}\text { Statistical significance of } \\
\text { dietary effects }\end{array}$} \\
\hline & & & & & & $\begin{array}{l}\text { Inclusion } \\
\text { rate }\end{array}$ & Cooking & Interaction \\
\hline \multicolumn{9}{|l|}{ Dry matter } \\
\hline lleal flow & $3 \cdot 38$ & $4 \cdot 48$ & $3 \cdot 43$ & $4 \cdot 73$ & $0 \cdot 334$ & $* *$ & NS & NS \\
\hline Faecal output & 1.09 & 1.63 & $1 \cdot 11$ & 1.61 & 0.033 & $* * *$ & NS & NS \\
\hline LB disappearance & $2 \cdot 29$ & $2 \cdot 86$ & $2 \cdot 33$ & $3 \cdot 12$ & $0 \cdot 321$ & * & NS & NS \\
\hline \multicolumn{9}{|l|}{ Organic matter } \\
\hline Ileal flow & 1.91 & $2 \cdot 99$ & 1.56 & $3 \cdot 31$ & 0.172 & $* * *$ & NS & NS \\
\hline Faecal output & $0 \cdot 70$ & 1.17 & 0.76 & 1.27 & 0.038 & $* * *$ & NS & NS \\
\hline LB disappearance & $1 \cdot 21$ & $1 \cdot 82$ & $0 \cdot 80$ & $2 \cdot 03$ & $0 \cdot 160$ & $* * *$ & NS & NS \\
\hline
\end{tabular}

Table 5. Large bowel tissue and digesta weights $(g)$ and transit times $(d)$ in rats given diets containing raw $(R)$ or cooked $(C)$ peas (Pisum sativum var. Sentinel) at two inclusion rates $(250(\mathrm{~L})$ and $500(\mathrm{H}) \mathrm{g} / \mathrm{kg})$

(Means for seven rats per diet)

\begin{tabular}{|c|c|c|c|c|c|c|c|c|}
\hline \multirow[b]{2}{*}{$\operatorname{Diet} \uparrow \ldots$} & \multirow[b]{2}{*}{$\mathrm{LC}$} & \multirow[b]{2}{*}{$\mathrm{HC}$} & \multirow[b]{2}{*}{ LR } & \multirow[b]{2}{*}{$\mathrm{HR}$} & \multirow[b]{2}{*}{ SEM } & \multicolumn{3}{|c|}{$\begin{array}{l}\text { Statistical significance of } \\
\text { dietary effects }\end{array}$} \\
\hline & & & & & & $\begin{array}{l}\text { Inclusion } \\
\text { rate }\end{array}$ & Cooking & Interaction \\
\hline \multicolumn{9}{|l|}{ Caecum } \\
\hline Organ mass & 3.45 & $4 \cdot 65$ & $3 \cdot 79$ & $2 \cdot 82$ & $0 \cdot 303$ & NS & NS & NS \\
\hline Wet digesta & $2 \cdot 65$ & $3 \cdot 68$ & 2.91 & $2 \cdot 95$ & $0 \cdot 266$ & NS & NS & NS \\
\hline Digesta DM & 0.44 & 0.64 & 0.49 & 0.54 & 0.046 & * & NS & NS \\
\hline Tissue & 0.79 & 0.96 & 0.87 & 0.86 & 0.052 & NS & NS & NS \\
\hline Transit time & 0.42 & 0.49 & 0.57 & $0 \cdot 39$ & 0.039 & NS & NS & $* *$ \\
\hline \multicolumn{9}{|l|}{ Colon } \\
\hline Organ mass & $1 \cdot 82$ & $2 \cdot 63$ & $1 \cdot 77$ & $2 \cdot 86$ & 0.156 & $* * *$ & NS & NS \\
\hline Wet digesta & 0.81 & $1 \cdot 49$ & $0 \cdot 75$ & $1 \cdot 73$ & 0.149 & $* * *$ & NS & NS \\
\hline Digesta DM & 0.27 & 0.48 & 0.24 & 0.58 & 0.062 & $* * *$ & NS & NS \\
\hline Tissue & 1.01 & $1 \cdot 14$ & $1 \cdot 01$ & $1 \cdot 13$ & 0.041 & $* *$ & NS & NS \\
\hline Transit time & 0.27 & $0 \cdot 41$ & $0 \cdot 29$ & $0 \cdot 45$ & 0.057 & * & NS & NS \\
\hline
\end{tabular}

NS, not significant; DM, dry matter.

$* P<0.05$;** $P<0.01$; ** $P<0.001$.

$\dagger$ For details of composition, see Table 1.

\$ For details of orthogonal contrasts, see p. 477. 
Table 6. $p H$, total volatile fatty acids (VFA) concentration (mmol/ $k g$ wet caecal contents) and molar proportions of the individual $V F A$ in the caeca of rats given diets containing raw $(R)$ or cooked $(C)$ peas (Pisum sativum var. Sentinel) at two inclusion rates $(250(L)$ and $500(H)$ $g / k g)$

(Means for seven rats per diet)

\begin{tabular}{|c|c|c|c|c|c|c|c|c|}
\hline \multirow[b]{2}{*}{$\operatorname{Diet}\lceil\ldots$} & \multirow[b]{2}{*}{$\mathrm{LC}$} & \multirow[b]{2}{*}{$\mathrm{HC}$} & \multirow[b]{2}{*}{ LR } & \multirow[b]{2}{*}{ HR } & \multirow[b]{2}{*}{ SEM } & \multicolumn{3}{|c|}{$\begin{array}{c}\text { Statistical significance of } \\
\text { dietary effects } \$\end{array}$} \\
\hline & & & & & & $\begin{array}{l}\text { Inclusion } \\
\text { rate }\end{array}$ & Cooking & Interaction \\
\hline Caecal pH & $6 \cdot 34$ & $6 \cdot 16$ & $6 \cdot 44$ & $6 \cdot 18$ & 0.057 & $* *$ & NS & NS \\
\hline $\begin{array}{l}\text { Total VFA (mmol } / \mathrm{kg} \\
\text { wet caecal contents) }\end{array}$ & 140 & 186 & 115 & 131 & $7 \cdot 3$ & $* * *$ & $* * *$ & NS \\
\hline \multicolumn{9}{|l|}{$\begin{array}{l}\text { Molar proportions of } \\
\text { individual VFA }(\mathrm{mmol} / \mathrm{mol})\end{array}$} \\
\hline Acetate & 649 & 678 & 619 & 615 & $9 \cdot 3$ & NS & $* * *$ & NS \\
\hline Propionate & 155 & 142 & 177 & 139 & $5 \cdot 8$ & NS & $* * *$ & NS \\
\hline Isobutyrate & 5 & 3 & 8 & 6 & 0.7 & $*$ & $* * *$ & NS \\
\hline Butyrate & 155 & 154 & 154 & 198 & 119 & NS & NS & NS \\
\hline Isovalerate & 8 & 3 & 14 & 10 & $1 \cdot 2$ & $* *$ & $* * *$ & NS \\
\hline Valerate & 14 & 9 & 16 & 14 & 1.4 & $*$ & $*$ & NS \\
\hline Hexanoate & 13 & 10 & 12 & 17 & $2 \cdot 4$ & NS & NS & NS \\
\hline
\end{tabular}

NS, not significant.

${ }^{*} P<0.05 ; * * P<0.01 ; * * * P<0.001$.

$\dagger$ For details of composition, see Table 1.

\pm For details of orthogonal contrasts, see p. 477 .

Table 7. Apparent digestibilities of non-starch polysaccharides (NSP) fraction and its constituents, and of resistant starch $(R S)$ in rats given diets containing raw $(R)$ or cooked $(C)$ peas (Pisum sativum var. Sentinel) at two inclusion rates $(250(\mathrm{~L})$ and $500(\mathrm{H}) \mathrm{g} / \mathrm{kg}$ )

(Means for seven rats per diet)

\begin{tabular}{|c|c|c|c|c|c|c|c|c|}
\hline \multirow[b]{2}{*}{ Diet $† \ldots$} & \multirow[b]{2}{*}{ LC } & \multirow[b]{2}{*}{$\mathrm{HC}$} & \multirow[b]{2}{*}{ LR } & \multirow[b]{2}{*}{ HR } & \multirow[b]{2}{*}{ SEM } & \multicolumn{3}{|c|}{$\begin{array}{c}\text { Statistical significance of } \\
\text { dietary effects } \neq\end{array}$} \\
\hline & & & & & & $\begin{array}{l}\text { Inclusion } \\
\text { rate }\end{array}$ & Cooking & Interaction \\
\hline NSP & 0.56 & $0 \cdot 63$ & 0.55 & 0.62 & 0.030 & $*$ & NS & NS \\
\hline Cellulose & $0 \cdot 14$ & $0 \cdot 38$ & 0.33 & 0.43 & 0.061 & $*$ & NS & NS \\
\hline NCP & $0 \cdot 79$ & 0.79 & 0.72 & 0.77 & 0.014 & NS & $*$ & NS \\
\hline Arabinose & $0 \cdot 98$ & 0.97 & 0.96 & 0.97 & 0.004 & NS & $*$ & NS \\
\hline Xylose & $0 \cdot 16$ & $0-37$ & $0 \cdot 21$ & 0.49 & $0 \cdot 062$ & $* * *$ & NS & NS \\
\hline Galactose & 0.63 & 0.75 & 0.57 & 0.72 & 0.026 & $* * *$ & NS & NS \\
\hline Glucose & 0.48 & 0.58 & 0.49 & 0.51 & $0 \cdot 202$ & NS & $*$ & NS \\
\hline Uronic acids & 0.89 & 0.89 & 0.83 & 0.88 & 0.014 & NS & $*$ & NS \\
\hline RS & 0.99 & 1.05 & 0.99 & 1.04 & 0.093 & NS & NS & NS \\
\hline
\end{tabular}

NCP, non-cellulosic polysaccharides; NS, not significant.

$* P<0.05 ; * * P<0.001$.

$\dagger$ For details of composition, see Table 1

$\ddagger$ For details of orthogonal contrasts, see p. 477 . 


\section{Digestibility of NSP and RS}

Digestibilities of total NSP were very similar for raw-pea diets and for cooked-pea diets and were greater for the diets containing $500 \mathrm{~g}$ peas compared with those containing $250 \mathrm{~g}$ peas $/ \mathrm{kg}$ diet (Table 7). Cellulose digestibility was lower than for total NSP and increased with the higher pea inclusion rate. The particularly low value recorded for cellulose digestibility with diet LC may be an artifact of the lower-than-expected analytical value for the cellulose content of this diet (Table 1). Digestibilities of the total non-cellulosic polysaccharides (NCP) fraction and of its monomers, arabinose and uronic acids, were significantly $(P<0.05)$ higher for the cooked-pea diets and unaffected by pea inclusion rate. In contrast, digestibilities of xylose and galactose were much higher for diets $\mathrm{HC}$ and HR than for diets LC and LR. Overall, digestibilities of NCP sugars were in the order arabinose $>$ uronic acids $>$ galactose $>$ xylose. Digestibility of RS was not significantly different from $1 \cdot 0$ for any diet.

\section{Blood concentration of $V F A$ and $3 O H B$}

Portal blood contained measurable concentrations of all those major VFA found in caecal contents and concentrations were increased with the higher-pea diets (Table 8 ). Cooking of peas before inclusion into the diet resulted in significantly $(P<0.01)$ lower concentrations of acetate in portal blood but had no other effects on the measured blood metabolites. Acetate was the only VFA detected reliably in heart blood and this too was higher with diets $\mathrm{HC}$ and HR than with diets LC and LR. Concentrations of $3 \mathrm{OHB}$ in both portal and heart blood tended to increase with the higher-pea diets but the difference was not statistically significant.

\section{DISCUSSION \\ Effects of cooking on dietary starch}

When compared with cereals, the rate of digestion of starch from leguminous seeds including peas is slow (Gee \& Johnson, 1985; Würsch et al. 1986) and this is reflected in reduced concentrations of glucose and insulin post prandially (Thorne et al. 1985; Tappy et al. 1986). This slow rate of starch digestion in raw peas is unlikely to be caused by $\alpha$ amylase inhibitors, since these are barely detectable (Goodlad, 1989), and appears to be due to the physical entrapping of starch within fibrous thick-walled parenchyma cells (Würsch et al. 1986). Starch in this form has been referred to as physically inaccessible starch $\left(\mathrm{RS}_{1}\right)$ by Englyst \& Kingman (1990). Cooking in water swells these starch granules and gelatinizes the starch and, especially when the cells are broken, increases starch digestion rate (Würsch et al. 1986). Our cooked-pea-containing diet had higher concentrations of starch resistant to $\alpha$-amylase without previous treatment with DMSO $\left(\mathrm{RS}_{3}\right)$ (Table 1$)$ so that it would appear that whilst cooking may have increased the potential rate of starch digestion, the subsequent cooling, freezing and freeze-drying more than balanced this through the formation of retrograded amylose ( $\mathrm{RS}_{3}$; Englyst \& Kingman, 1990). Bach Knudsen et at. (1988) reported that cooking and subsequent cooling with or without freeze-drying greatly increased the concentration of RS in sorghum (Sorghum bicolor (L.) Moench).

\section{Food intake, growth and body composition}

Diets containing raw and cooked peas were well accepted by the rats. The lower DM intakes observed with the higher pea inclusion rate is a consequence of the slightly lower DM content of these diets. The statistically significant $(P<0 \cdot 05)$ interaction between inclusion rate and cooking on growth rate is due to the $10 \%$ greater growth rate by animals given diet LR with very similar growth rates for the other three diets. We have no 
Table 8. Concentrations of volatile fatty acids $(V F A ; \mu M)$ and of 3-hydroxybutyrate $(3 O H B$; $\mu M)$ in whole blood from rats given diets containing raw $(R)$ or cooked $(C)$ peas (Pisum sativum var. Sentinel) at two inclusion rates $(250(L)$ and $500(H) \mathrm{g} / \mathrm{kg})$

(Means for seven rats per diet)

\begin{tabular}{|c|c|c|c|c|c|c|c|c|}
\hline \multirow[b]{2}{*}{$\operatorname{Diet}^{\dagger} \ldots$} & \multirow[b]{2}{*}{ LC } & \multirow[b]{2}{*}{$\mathrm{HC}$} & \multirow[b]{2}{*}{ LR } & \multirow[b]{2}{*}{ HR } & \multirow[b]{2}{*}{ SEM } & \multicolumn{3}{|c|}{$\begin{array}{c}\text { Statistical significance of } \\
\text { dietary effects } \$\end{array}$} \\
\hline & & & & & & $\begin{array}{l}\text { Inclusion } \\
\text { rate }\end{array}$ & Cooking & Interaction \\
\hline \multicolumn{9}{|l|}{ Portal blood } \\
\hline Acetate & 690 & 709 & 754 & 968 & $52 \cdot 1$ & $*$ & $* *$ & NS \\
\hline Propionate & 103 & 156 & 104 & 174 & $12 \cdot 6$ & $* * *$ & NS & NS \\
\hline Butyrate & 59 & 88 & 49 & 103 & 8.6 & $* * *$ & NS & NS \\
\hline $3 \mathrm{OHB}$ & 53 & 54 & 57 & 69 & $12 \cdot 1$ & NS & NS & NS \\
\hline \multicolumn{9}{|l|}{ Heart blood } \\
\hline Acetate & 596 & 693 & 529 & 620 & $41 \cdot 3$ & * & NS & NS \\
\hline $3 \mathrm{OHB}$ & 5 & 90 & 89 & 94 & $12 \cdot 3$ & NS & NS & NS \\
\hline
\end{tabular}

NS, not significant.

* $P<0.05 ;{ }^{* *} P<0.01 ; * * * P<0.001$.

$\dagger$ For details of composition, see Table 1.

$\ddagger$ For details of orthogonal contrasts, see p. 477 .

satisfactory explanation for this observation, although it is worth noting that diet LR produced the greatest $\mathrm{N}$ retention so the effect may be real. It appeared that diet had no marked effect on the composition (fat:lean ratio) of live-weight gain since the ratio of weight gain: $\mathrm{N}$ retention was similar for all diets. The very highly significantly lower liver weights with the high-pea diets may indicate lower contents of glycogen and lipid (Pedroso et al. 1990).

\section{Sites and extents of digestion}

We were unable to detect any effect of cooking on the flow of OM from the terminal ileum or on the amount of OM apparently fermented in the LB (Table 4). Since the OM flowing into the LB was not chemically fractionated, we do not know whether cooking altered the composition of this OM, e.g. exchanging $\mathrm{RS}_{1}$ for $\mathrm{RS}_{3}$. With $500 v .250 \mathrm{~g}$ peas $/ \mathrm{kg}$ diet included at the expense of the highly digestible sucrose and casein, there were significant increases in the flows of DM and OM from the terminal ileum (Table 4). As a proportion of ingested OM, ileal OM flow increased from $0 \cdot 10$ to $0 \cdot 19$ with $250 v .500 \mathrm{~g}$ peas $/ \mathrm{kg}$ diets. If it is assumed that all the ingested NSP and RS escaped digestion in the small intestine (Englyst \& Cummings, 1985), then it may be calculated that these fractions accounted for 0.35 (low-pea diets) and 0.41 (high-pea diets) of the ileal OM flow. This suggests that there are substantial amounts of other substances probably including oligosaccharides, proteins and starch of food origin and endogenous materials contributing to LB substrate supply (Cummings \& Englyst, 1987).

Much of the OM entering the caecum (0.57 and 0.61 for low- and high-pea diets respectively) did not appear in the faeces (Table 5), and it is assumed that this material was fermented largely within the caecum since digestibilities measured at the level of the colon were similar to those for faeces (Table 3). True digestibility of OM within the LB will have been greater than this since some of the fermented OM will have been used for synthesis of bacterial cells. The latter is estimated to be $263 \mathrm{mg}$ bacterial OM/g OM truly fermented 
(Mathers, 1991) from values given by Cummings (1984). The greater faecal $\mathrm{N}$ output with the higher-pea diets (Table 2) is consistent with increased bacterial cell output (Goodlad \& Mathers, 1990) as a result of the greater OM fermentation with these diets. In sheep, starch infused into the caecum was extensively fermented and increased faecal $\mathrm{N}$ output (Ørskov et al. 1970).

Whilst cooking may influence the degree of polymerization of NSP in foods (Waldron \& Selvendran, 1990), the limited information available (Björck et al. 1984; Fadel et al. 1988, 1989) suggest that thermal processing (baking or extrusion cooking) of cereals has only small effects on NSP digestibility. This was confirmed in the present study where digestibilities of total NSP from raw and boiled peas were not significantly different. Whilst cooking did tend to increase the digestibilities of NCP and its constituent sugars, perhaps through disruption of plant cell walls and partial hydrolysis of their polymeric constituents (Waldron \& Selvendran, 1990), the nutritional consequences of such small changes are likely to be minor. NSP digestibility was lower for cooked than for raw peas when tubefed to cockerels (Longstaff \& McNab, 1987).

In the earlier studies (Goodlad \& Mathers, 1990, 1991; Key \& Mathers, 1990) it was reported that variations in the dietary intake of NSP from raw peas or cooked haricot beans (Phaseolus vulgaris) were matched by proportional changes in faecal NSP output in both rats and pigs, i.e. that each increment in NSP intake resulted in equally effective NSP digestion. The significantly higher apparent digestibilities of NSP and some of the monomeric constituents, notably xylose and galactose with its higher dietary pea inclusion rate (Table 7) in the present experiment were, therefore, unexpected, and indicated that it may not always be safe to assume that digestibility of the NSP in a food is independent of intake. Apparent digestibilities of NSP and of its constituents in the peas (var. Sentinel) used in the present study were lower than for those (var. Progreta) reported earlier (Goodlad \& Mathers, 1990). The total NSP and their monosaccharide constituents were similar for both varieties (Goodlad, 1989) so cannot explain this apparent between-variety difference in digestibility.

RS prepared from pea starch by autoclaving then cooling to $1^{\circ}$ for $72 \mathrm{~h}$ was more slowly fermented in vitro in dilute incubations with caecal contents from rats or fresh human faeces than was maize RS prepared in the same way (Wyatt \& Horn, 1988). In vivo evaluation of similar products indicated that pea RS was relatively poorly digested by the rat in the first few days after introduction to the diet, but by 17-18 $\mathrm{d}$ the difference in apparent digestibility between the two sources of RS was reduced and both were $\geqslant 0.9$ (Faulks et al. 1989). We could not detect consistently any RS in the faeces from our rats and assume that it was virtually all fermented.

\section{$L B$ fermentation}

Feeding cooked $v$. raw peas had no significant effects on caecal or colonic tissue or contents weights. However, rats fed on diets with the higher inclusion rate of peas had greater LB digesta weights, especially for the colon, and also much longer colonic TT (Table 5). These findings suggest that with the higher intakes of fermentable material some spill-over of fermentation into the colon may have occurred and the longer LB TT may have contributed to the higher NSP digestibilities recorded with these diets.

The mass of digesta in the caecum and colon was positively associated with tissue weight for both organs, as described previously by Wyatt et al. (1988) and Goodlad \& Mathers (1990) (caecum only). Since the accumulation of digesta in the caecum was independent of the flow-rate of DM or OM into the organ or of the amount of OM fermented in the LB, in agreement with the observations by Mathers \& Dawson (1991), the factors influencing LB hypertrophy remain unclear. 
Table 9. Calculated absorption $\dagger$ of volatile fatty acids $(V F A ; m m o l / d)$ from the large bowel and its contribution to metabolizable energy $(M E)$ intake in rats given diets containing raw $(R)$ or cooked $(C)$ peas (Pisum sativum var. Sentinel) at two inclusion rates $(250(L)$ and $500(H)$ $\mathrm{g} / \mathrm{kg}$ )

(Means for seven rats per diet)

\begin{tabular}{|c|c|c|c|c|c|c|c|c|}
\hline \multirow[b]{2}{*}{$\operatorname{Diet}^{\dagger}$. } & \multirow[b]{2}{*}{$\mathrm{LC}$} & \multirow[b]{2}{*}{$\mathrm{HC}$} & \multirow[b]{2}{*}{ LR } & \multirow[b]{2}{*}{$\mathrm{HR}$} & \multirow[b]{2}{*}{ SEM } & \multicolumn{3}{|c|}{$\begin{array}{c}\text { Statistical significance of } \\
\text { dietary effects§ }\end{array}$} \\
\hline & & & & & & $\begin{array}{l}\text { Inclusion } \\
\text { rate }\end{array}$ & Cooking & Interaction \\
\hline Acetate & $8 \cdot 8$ & $13 \cdot 1$ & $5 \cdot 5$ & $13 \cdot 4$ & $1 \cdot 22$ & $* * *$ & NS & NS \\
\hline Propionate & $2 \cdot 1$ & $2 \cdot 7$ & $1 \cdot 5$ & $2 \cdot 8$ & $0 \cdot 30$ & $* * *$ & NS & NS \\
\hline Butyrate & $2 \cdot 0$ & $3 \cdot 3$ & 1.4 & $4 \cdot 4$ & $0 \cdot 35$ & $* * *$ & NS & NS \\
\hline Total & $12 \cdot 9$ & $19 \cdot 2$ & 8.4 & $20 \cdot 7$ & 1.72 & $* * *$ & NS & NS \\
\hline $\begin{array}{l}\text { Proportion of } \\
\text { ME intake }\end{array}$ & 0.05 & 0.08 & 0.04 & 0.09 & 0.007 & $* * *$ & NS & NS \\
\hline
\end{tabular}

NS, not significant.

$* * * P<0-001$.

+ Calculated from organic matter disappearance in the large bowel (Table 4) and caecal VFA molar proportions (Table 6) assuming conventional anaerobic stoichiometry (Demeyer \& Van Nevel, 1975).

$¥$ For details of composition, see Table 1 .

$\S$ For details of orthogonal contrasts, see p. 477.

Higher intakes of peas resulted in lower caecal $\mathrm{pH}$ and higher total VFA concentrations as expected from the greater daily rate of OM fermentation in that organ. The higher total VFA concentration with cooked than with raw peas may indicate a faster rate of $\mathrm{OM}$ fermentation occurring at the time of sampling caused not by greater OM flow from the terminal ileum (Table 4 ) but possibly by more ready access to cell-wall polysaccharides. Although cooking has only minor effects on the extent of NSP fermentation (Table 7), it may alter the rate and this deserves further investigation.

Changes in VFA molar proportions with alterations in diet composition were not as marked as in some earlier studies (Key \& Mathers, 1987, 1988; Mathers et al. 1990; Goodlad \& Mathers, 1990) possibly because of smaller contrasts in the amount and nature of substrates supplied to the LB. The reason for the higher acetate molar proportion with the cooked-pea diets is unknown. We have observed relatively high acetate concentrations both in vitro (Goodlad \& Mathers, 1988) and in vivo (Mathers \& Finlayson, 1989) with pectin as substrate. The latter is rapidly fermented so it is possible that differences in rate of fermentation could have contributed to the altered VFA pattern observed between rawand cooked-pea diets. The reduced proportions of branched-chain VFA and of valerate with the cooked-pea diets could indicate their greater utilization for de novo amino acid and, hence, bacterial protein synthesis (Russell \& Hespell, 1981). Alternative possibilities include either less protein flowing from the terminal ileum or that the heat-treated dietary protein escaping small intestinal digestion was also less susceptible to LB fermentation.

\section{Absorption of fermentation end-products}

Amounts of VFA calculated to be absorbed from the LB (Table 9) were almost doubled by the doubling of pea-inclusion rate in the diets with no significant effects of cooking. These increased absorption rates were reflected in higher concentrations of VFA in portal 
and, for acetate only, in heart blood. The significantly higher concentrations of acetate in portal blood with the raw-pea diets may indicate that, at the time of blood sampling $(4-7 \mathrm{~h}$ after presentation of the last meal), the instantaneous rate of LB fermentation was higher for animals consuming raw peas compared with cooked peas. In agreement with results from our earlier study (Goodlad \& Mathers, 1990), the rat liver removed all detectable propionate and butyrate but only a portion of the acetate supplied by the LB via the portal vein, so that direct effects of substrate supply on metabolism is anticipated for both liver (Pedroso et al. 1990) and extrahepatic tissues.

In conclusion, cooking peas had only minor effects on the extent of digestion of NSP but may have altered the rate and sites of starch digestion, as evidenced by caecal fermentation changes. Fractionation of the OM flowing into the LB and detailed study of the rates of hydrolysis of individual complex carbohydrates by the LB flora may aid understanding of the effects of culinary processes on LB fermentation and subsequent implications for tissue metabolism and health.

The authors thank SERC for a CASE award (J.S.G.) in cooperation with Unilever Research, Colworth Laboratory, Bedford and R. Mawson for his interest.

\section{REFFRENCES}

Bach Knudsen, K. E., Munck, L. \& Eggum, B. O. (1988). Effect of cooking, pH and polyphenol level on carbohydrate composition and nutritional quality of a sorghum (Sorghtm bicolor (L.) Moench) food, ugali. British Journal of Nutrition 59, 31-47.

Björck, I., Nyman, M. \& Asp, N.-G. (1984). Extrusion cooking and dietary fiber: effects on dietary fiber content and on degradation in the rat intestinal tract. Cereal Chemistry 61, 174-179.

Cheng, B.-Q., Trimble, R. P., Hlman, R. J., Stone, B. A. \& Topping, D. L. (1987). Comparative effects of dietary wheat bran and its morphological components (aleurone and pericarp-seed coat) on volatile fatty acid concentrations in the rat. British Journal of Nutrition 57, 69-76.

Collings, P.. Williams, C. \& Macdonald, I. (1981). Effects of cooking on serum glucose and insulin responses to starch. British Medical Journal 282, 1032.

Collinson, R. (1968). Starch retrogradation. In Starch and Its Derivatives, pp. 194- 202 [J. A. Radley, editor]. London: Chapman \& Hall.

Cummings, J. H. (1984). Microbial digestion of complex carbohydrates in man. Proceedings of the Nutrition Society 43, 3544.

Cummings, J. H. \& Englyst, H. N. (1987). Fermentation in the human large intestine and the available substrates. American Journal of Clinical Nutrition 45, 12431255.

Demeyer, D. I. \& Van Nevel, C. J. (1975). Methanogenesis, an integrated part of carbohydrate fermentation, and its control. In Digestion and Metabolism in the Ruminant, pp. 366-382 [I. W. McDonald and A. C. I. Warner, editors]. Armidale: University of New England Publishing Unit.

Englyst, H. N. \& Cummings, J.H. (1984). Simplified method for the measurement of total non-starch polysaccharides by gas-liquid chromatography of constituent sugars as the alditol acetates. Analyst 109, 937-942.

Englyst, H. N. \& Cummings, J. H. (1985). Digestion of the polysaccharides of some cereal foods in the human small intestine. American Joumal of Clinical Nutrition 42, 778- 787.

Englyst, H. N. \& Cummings, J. H. (1987). Resistant starch, a 'new' food component : a classification of starch for nutritional purposes. In Cereals in a European Context, pp. 221-233 [1. D. Morton, editor], Chichester: Ellis Horwood Ltd.

Englyst, H. N. \& Kingman, S. M. (1990). Dietary fiber and resistant starch. A nutritional classification of plant polysaccharides. In Dietary Fiber, pp. 4965 [D. Kritchevsky, C. Bonfield and J. W. Anderson, editors]. New York: Plenum Publishing Corporation.

Fadel, J. G., Newman, C. W., Newman, R. K. \& Graham, H. (1988). Effects of extrusion cooking of barley on ileal and fecal digestibilities of dietary components in pigs. Canadian Journal of Animal Science 68, 891-897.

Fadel, J. G., Newman, R. K., Newman, C. W. \& Graham, H. (1989). Effects of baking hulless barley on the digestibility of dietary components as measured at the ileum and in the feces in pigs. Journal of Nutrition 119 , 722.726 .

Faulks, R. M., Southon, S. \& Livesey, G. (1989). Utilization of $\alpha$-amylase (EC 3.2.1.1) resistant maize and pea (Pisum sativum) starch in the rat. British Joumal of Nutrition 61, 291-300.

Gee, J. M. \& Johnson. I. T. (1985). Rates of starch hydrolysis and changes in viscosity in a range of common foods subjected to simulated digestion in vitro. Journal of the Science of Food and Agriculture 36, 614-620. 
Goodlad, J. S. (1989). Digestion and large intestinal fermentation of pea (Pisum sativum) carbohydrates. PhD Thesis, University of Newcastle upon Tyne.

Goodlad, J. S. \& Mathers, J. C. (1988). Effects of food carbohydrates on large intestinal fermentation in vitro. Proceedings of the Nutrition Society 47, 176A.

Goodlad, J. S. \& Mathers, J. C. (1990). Large bowel fermentation in rats given diets containing raw peas (Pisum sativum). British Journal of Nutrition 64, 569-587.

Goodlad, J. S. \& Mathers, J. C. (1991). Digestion by pigs of non-starch polysaccharides in wheat and raw peas (Pisum sativum) fed in mixed diets. British Journal of Nutrition 65, 259-270.

Grant. G., More, L. J., McKenzie, N. H., Stewart, J. C. \& Pusztai, A. (1983). Survey of the nutritional and haemagglutination properties of legume seeds generally available in the UK. British Journal of Nutrition $\mathbf{5 0}$, $207-214$.

Holm, J., Lundquist, I., Björck, I., Eliasson, A.-C. \& Asp, N.-G. (1988). Degree of starch gelatinization, digestion rate of starch in vitro, and metabolic response in rats. American Journal of Clinical Nutrition 47, $1010-1016$.

Huisman, J., Van der Poel, A. F. B., Van Leeuwen, P. \& Verstegen, M. W. A. (1990). Comparison of growth, nitrogen metabolism and organ weights in pigs and rats fed on diets containing Phaseolus vulgaris beans. British Journal of Nutrition 64, 743-753.

Key, F. B. \& Mathers, J. C. (1987). Response of rat caecal metabolism to varying proportions of white and wholemeal bread. Proceedings of the Nutrition Society 46, 11 A.

Key, F. B. \& Mathers, J. C. (1988). Response of rat caecal metabolism to white and wholemeal breads given at two fat levels. Proceedings of the Nutrition Society 47, 101A.

Key, F. B. \& Mathers, J. C. (1990). Estimation of the digestibilities of NSP for wholemeal bread and haricot beans fed in mixed diets. In Dietary Fibre: Chemical and Biological Aspects, pp. 254-258 [D. A. T. Southgate, K. Waldron, I. T. Johnson and G. R. Fenwick, editors]. Cambridge : Royal Society of Chemistry.

Liener. I. E. \& Kakade, M. L. (1980). Protease inhibitors. In Toxic Constituents of Plant Foodstuffs, pp. 7-71 [I. E. Liener, editor]. New York: Academic Press.

Lloyd, B., Burrin, J., Smythe, P. \& Alberti, K. G. M. M. (1978). Enzymic fluorometric continuous flow assays for blood glucose, lactate, pyruvate, alanine, glycerol and 3-hydroxybutyrate. Clinical Chemistry 34, 1724-1729.

Longstaff, M. \& McNab, J. M. (1987). Digestion of starch and fibre carbohydrates in peas by adult cockerels. British Poultry Science 28, 261-285.

Macfarlane, G. T. \& Englyst, H. N. (1986). Starch utilization by the human large intestinal microflora. Journal of Applied Bacteriology 60, 195-201.

Mathers, J. C. (1991). Digestion of non-starch polysaccharides by non-ruminant omnivores. Proceedings of the Nutrition Society 50, 161-172.

Mathers, J. C. \& Dawson, L. D. (1991). Large bowel fermentation in rats eating processed potatoes. British Journal of Nutrition 66, 313-329.

Mathers, J. C., Fernandez, F., Hill, M. J., McCarthy, P. T., Shearer, M. J. \& Oxley, A. (1990). Dietary modification of potential vitamin $\mathrm{K}$ supply from enteric bacterial menaquinones in rats. British Journal of Nutrition 63, 639-652.

Mathers, J. C. \& Finlayson, H. J. (1989). Manipulation of rat caecal metabolism by including Avoparcin and pectin in the diet. Proceedings of the Nutrition Society 48, 139A.

O'Dea, K., Snow, P. \& Nestel, P. (1981). Rate of starch hydrolysis in vitro as a predictor of metabolic responses to complex carbohydrate in vivo. American Joumal of Clinical Nutrition 34, 1991-1993.

Orford, P. D., Ring, S. G., Carroll, V., Miles, M. J. \& Morris, V. J. (1987). The effect of concentration and botanical source on the gelation and retrogradation of starch. Journal of the Science of Food and Agriculture 39, $169-177$.

Ørskov, E. R., Frazer, C., Mason, V. C. \& Mann, S. O. (1970). Influence of starch digestion in the large intestine of sheep on caecal fermentation, caecal microflora and faecal nitrogen excretion. British Journal of Nutrition $\mathbf{2 4}$, $671-682$.

Paul, A. A. \& Southgate, D. A. T. (1978). McCance and Widdowson's The Composition of Foods. 4th revised ed. London: H.M. Stationery Office.

Pedroso, L. M. R., Mathers, J. C. \& Finlayson, H. J. (1990). Effect of raw peas on activities of key enzymes of lipid and carbohydrate metabolism in rat liver. Proceedings of the Nutrition Society 49, 52A.

Ridgman, W. J. (1975). Experimentation in Biology. Glasgow and London: Blackie.

Russell, J. B. \& Hespell, R. B. (1981). Microbial rumen fermentation. Journal of Dairy Science 64, 1153-1169.

Sharon, N. \& Halina, L. (1972). Lectins; cell-agglutinating and sugar specific proteins. Science 177, 949-959.

Tappy, L., Würsch, P., Randin, J. P., Felber, J. P. \& Jéquier, E. (1986). Metabolic effect of pre-cooked instant preparations of bean and potato in normal and in diabetic subjects. American Journal of Clinical Nutrition 43, $30-36$.

Thompson, A. (1970). Rat metabolism cage. Journal of the Institute of Animal Technicians 21, 12-21.

Thorne, M. J., Thompson, L. U. \& Jenkins, D. J. A. (1985). Factors affecting starch digestibility and the glycemic response with special reference to legumes. American Journal of Clinical Nutrition 38, 481-488.

Waldron, K. W. \& Selvendran, R. R. (1990). Changes in dietary fibre polymers during storage and cooking. In Dietary Fibre: Chemical and Biological Aspects, pp. 44-49 [D. A. T. Southgate, K. Waldron, I. T. Johnson and G. R. Fenwick, editors]. Cambridge: Royal Society of Chemistry. 
Würsch, P., Del Vedovo, S. \& Koellreulter, B. (1986). Cell structure and starch nature as key determinants of the digestion rate of starch in legumes. American Journal of Clinical Nutrition 43, 25-29.

Wyatt, G. M. \& Horn, N. (1988). Fermentation of resistant food starches by human and rat intestinal bacteria. Journal of the Science of Food and Agriculture 44, 281-288.

Wyatt, G. M., Horn, N., Gee, J. M. \& Johnson, I. T. (1988). Intestinal microflora and gastrointestinal adaptation in the rat in response to non-digestible dietary polysaccharides. British Journal of Nutrition 60, 197-207. 